\title{
Increasing awareness about the neonatal care of fathers whose babies are hospitalized in neonatal intensive care unit
}

\author{
Harun Özbey ${ }^{1}$, Illknur Kahriman*2 \\ ${ }^{1}$ Erciyes University, Department of Pediatric Nursing, Faculty of Health Sciences, Kayseri, Turkey \\ ${ }^{2}$ Karadeniz Technical University, Faculty of Health Sciences, Department of Pediatric Nursing, Trabzon, Turkey
}

Received: February 14, 2018

DOI: $10.5430 /$ cns.v6n3p72
Accepted: March 13, 2018

URL: https://doi.org/10.5430/cns.v6n3p72
Online Published: April 12, 2018

\begin{abstract}
Objective: This research was conducted to determine the efficiency of the training given to the fathers whose babies were hospitalized in the neonatal intensive care unit regarding the improvement of awareness about "Newborn Care" and to develop their awareness about it.

Methods: In this experimental study including pre/post tests and control group, the fathers in the experimental group were given theoretical training and brochures about neonatal care. No training was provided to the fathers in the control group. They were only given visually enriched brochures. The data were collected using a father identification form and an information form including questions to determine the knowledge levels of the fathers level about newborn care. In the analysis of the data, numbers, percentages, distributions, Wilcoxon test for the comparison of pre/post training scores, Mann-Whitney U test for the comparison of two independent groups, and chi-square test for the comparison of socio-demographic characteristics of fathers were used. The significance level was accepted as $p<.05$. Institutional and ethics committee permissions were obtained for the research.

Results: While pre-training knowledge scores of the fathers in the experimental and control groups were $12.24 \pm 12.24$ and $12.48 \pm 8.46$ respectively, their post training scores increased up to $42.98 \pm 3.70$ and $18.60 \pm 6.05$ and the difference between them was statistically significant $(\mathrm{Z}=-6.157, p=.00 ; \mathrm{Z}=-5.297, p=.00)$. When the experimental and control groups were compared in terms of knowledge scores, while the pre-training scores were found similar, the post training scores in the experimental group were significantly higher than those of the control group ( $p=.23, p=.00$, respectively).

Conclusions: According to these data, the training given to the fathers was found to be effective and their awareness of basic new born care increased.
\end{abstract}

Key Words: Father, Training, Nursing, Newborn

\section{INTRODUCTION}

Family is the smallest unit of a society and the most important social environment that shapes the child's development and behavior and enables his/her growth and development.
The fact that all the individuals constituting the family, especially children, are physically, mentally and environmentally healthy affects the development of the society positively. ${ }^{[1]}$ There are many factors that influence the health of all family

\footnotetext{
*Correspondence: IIlknur Kahriman; Email: ilknurkahriman@ @otmail.com; Address: Karadeniz Technical University, Faculty of Health Sciences, Department of Pediatric Nursing, Trabzon, Turkey.
} 
members. Some of these factors are marital expectations, experiences, age, education levels, occupations, psychological, social and economic resources, various natural phenomena and social situations. Another factor that also affects the family health is the "perinatal" period, which includes antenatal, natal and postnatal processes. This period is an important crisis period affecting a family structure. ${ }^{[2]}$

The postpartum, an important milestone in the protection and development of family health and the last part of the perinatal period, is a period when parents experience intense stress, and when there are physiological and psychological changes in parents and especially in the newborn. ${ }^{[1]}$ Parents gain new roles and responsibilities with a new member joining the family during this period. This period is of immense importance for the health of the child, because it requires parents' preparation and compliance with these roles and responsibilities. ${ }^{[3]}$ The fact that a father supports his wife well during the postpartum period helps her to find time for herself apart from baby care and this improves both their family and social relations. In addition, the father's support for the mother during the postpartum period is also very important in terms of the health of the newborn. ${ }^{[4]}$ The postpartum period can be experienced as a period of crisis as well as a period in which the parents and newborns are very positive and their family ties strengthen. ${ }^{[5]}$ In a study, it was found that fathers' caring of their baby in the postpartum period increased their confidence, intellectual ability, empathy and social skills while reducing their depression, behavioral problems, hyperactivity and aggression tendency in their children in later periods. ${ }^{[6]}$

The fact that the fathers participates in the postnatal period and supports his wife is known to decrease the depression frequency in the mother and strengthen the communication within the family. It was also found to reduce drug addiction in fathers and reduce mental fatigue. ${ }^{[7]}$ The participation of fathers in the postpartum period and baby care was reported to increase their prolactin levels and the testosterone hormones respectively. ${ }^{[8-10]}$ In another study, it was stated that oxytocin levels in blood samples taken from fathers experiencing fatherhood for the first time increased and there was a correlation between oxytocin level and the time spent with the baby. ${ }^{[11]}$

Ensuring that the fathers are informed about baby care and their participation in baby care will contribute to supporting mothers at home after their baby is discharged. That the mother who takes care of the baby all day long is supported by the father in the postpartum period can help the mother to allocate more time to herself, do social life activities. It develops a positive relation between the mother and the father

Published by Sciedu Press and prevents the crises and recognizing the health problems that can be experienced in this period. It will also increase the awareness of fathers about newborn care, make it easier for them to adopt the fatherhood role and eliminate the fear, anxiety and worry caused by the lack of knowledge. This research was conducted to determine the efficiency of the training given to the fathers whose babies were in the newborn intensive care unit to raise their awareness about "Newborn Care".

\section{Methods}

\subsection{Research design}

In this study, "Experiment and Control Group with Pre/Post Test Model", one of the Quasi-Experimental study methods, was used. The study was conducted with a total of 100 voluntary fathers, 50 in control and 50 in experimental groups, whose babies were hospitalized in the neonatal intensive care unit in a university hospital between March 2017 and July 2017. In the study, both theoretical and brochure training were provided to the experimental group but only the brochure training was given to the control group.

In order to prevent the interaction between the groups during the application period, the data from the experiment group were collected first. Each week on Wednesday, the fathers in the experimental group were applied a pretest to measure their baby care knowledge in the meeting room of the clinic after their meeting with the service doctor about their baby's health and then a training was provided to the fathers about newborn care in the experimental group (content of the training: baby skin care, rash care, umbilical care, mouth, eye, nose and nail care, baby carrying baby, baby bath, changing the diaper, causes for crying, sleeping patterns, fever measurement and baby care with fever, baby safety, vaccination schedule and vaccination reactions, monitoring of growth, baby feeding, breastfeeding, initiation of supplementary foods, gas pains, baby massage, screening tests, clothing selection) and then visually enriched brochures were given. 15 days after the training, the post test was applied. The fathers in the control group were pre-tested during the admission of the babies, visually enriched brochures were given but no application was performed to them until the time when their babies were scheduled to be discharged. The post test was given while their baby's discharge was planned.

\section{Research question}

What are the knowledge levels of the fathers whose babies are hospitalized in the neonatal intensive care unit?

Is there a difference between the theoretical and brochure training and the brochure training alone in increasing fathers' knowledge level? 


\subsection{Data collection}

The data were collected through a "Father Identification Form" consisting of 11 questions to identify the SocioDemographic characteristics of the fathers and an "Assessment Form of Fathers' Knowledge Levels about Neonatal Care" including 46 questions to measure the fathers' knowledge level about neonatal care.

Father Identification Form was prepared by the researcher in the light of the literature. This form includes 11 questions and was designed to provide the information on fathers' age, educational levels, occupations, employment status, the places they lived the longest, family types, incomes, whether they received a newborn care training before, if yes, from whom they received this training, their views about participating in their babies care after the discharge.

An "Assessment Form of Fathers' Knowledge Levels what can be levels? What criteria of levels? about Neonatal Care" was prepared by the researchers with the aim of measuring the knowledge level of fathers about neonatal care using the literature. This form includes the questions regarding baby skin care, rash care, umbilical care, throat, eye, nose and nail care, carrying baby, baby bath, changing the diaper, the reason for crying, sleeping patterns, fever measurement and baby care with fever, baby safety, vaccination schedules and vaccination reactions, monitoring of growth, baby feeding and breastfeeding, initiation of supplementary foods, gas pains, baby massage, screening tests and clothing selections. In this form, the correct and incorrect answers were recorded as 1 and 0 respectively and the total correct answers for each father were calculated between $0-46$ points. The knowledge levels are low between 0-15 points, 16-30 points between intermediate and 31-46 points are considered high. The questionnaire forms were prepared as a pre/post test format and the same questionnaire forms were used in both groups.

\subsection{Ethical considerations}

This study was carried out in accordance with the Helsinki Declaration principles. For the application the study ethical permission was received on 24-03-2017 and the institutional permission was obtained from the chief of the university hospital where the research was conducted on 25-01-2017. In addition, the fathers were ensured to participate in the study voluntarily. Verbal Permission was obtained from fathers.

\subsection{Statistical analyses}

The distributions of the correct/incorrect answers obtained in the pre and post tests were made through descriptive statistics. 1 point was given to the correct answers of the questions on baby care. Pre and post test scores were obtained by collecting the correct answers in the experimental and con- trol groups in the pre and post tests. In the analysis of the data, numbers, percentages, distributions, Wilcoxon test for the comparison of pre/post training scores, Mann-Whitney U test for the comparison of two independent groups, and chi-square test for the comparison of socio-demographic characteristics of fathers were used. $P<.05$ was accepted as the significance value.

\section{RESULTS}

The study findings showed that in the experimental group $62.0 \%$ of the fathers were in the age group of 35 and under, $40.0 \%$ were high school graduates, $64.0 \%$ were living in the city, $68 \%$ had a nuclear family, $38 \%$ had three and more children, and $46 \%$ had sufficient income. In the control group $72.0 \%$ of them were in the age group of 35 and under, $40.0 \%$ were high school graduates, $48.0 \%$ were living in the city, $76 \%$ had a nuclear family structure, and $42.0 \%$ had three or more children, and $32.0 \%$ had insufficient income. At the end of the theoretical training in the experimental groups, the knowledge scores of the fathers who were 35 years old and under, primary school graduates, employed, living in the districts, had a nucleus family, had equal income and expenses and had 2 and more children were higher than the other groups. There was a significant difference between the knowledge scores of the fathers in the experimental group and the number of children at the end of the training ( $p<$ $.05)$. In the control group, it was seen that the knowledge scores of those in the age group of 35, university graduates, employed, living in the districts, had a nucleus family and had sufficient income increased more compared to the others at the end of the brochure training $(p>.05)$ (see Table 1).

The study findings showed that the majority of the fathers both in the experimental (70.0\%) and control groups (68.0\%) did not have baby care experience with their own baby or the baby of another person before and the knowledge scores of those who had baby care experience increased more. The majority of the fathers in the experimental and control groups did not receive any training in neonatal care before $(86.0 \%$, $78.0 \%$ ). The knowledge scores of the fathers in both groups who had previously received neonatal care training were higher than those who did not, but no statistically significant difference was found between the status of receiving neonatal care training and the knowledge scores of the fathers in both groups $(p>.05)$. The majority of the fathers in the experiment and control group (71.4\%, $45.4 \%$ respectively) who had basic neonatal care training earlier received it from health staff and the majority of the fathers in both groups stated that they would like to participate in their child care after discharge $(98.0 \%, 74.0 \%)$ (see Table 2).

The pre-training knowledge scores of the fathers in the ex- 
perimental and control groups were low were respectively were compared in terms of the knowledge scores, the pre$12.24 \pm 12.24$ and they increased up to $42.98 \pm 3.70$ and training knowledge scores were similar, whereas the post $18.60 \pm 6.05$ after the training. A significant difference was training scores in the experimental group were found to be found $(\mathrm{Z}=-6.157, p=.00 ; \mathrm{Z}=-5.297, p=.00)$ between significantly higher than those of the control group $(p=.23$, these scores. When the experimental and control groups $p=.00$ ) (see Table 3).

Table 1. The comparison of baby care knowledge scores of the fathers according to their Socio-Demographic characteristics

\begin{tabular}{|c|c|c|c|c|c|c|c|c|}
\hline \multirow[b]{2}{*}{ Variables } & \multicolumn{4}{|c|}{ Experimental Group } & \multicolumn{4}{|c|}{ Control Group } \\
\hline & $\mathbf{n}$ & $\%$ & $\begin{array}{l}\text { Pre test mean } \\
\text { rank }\end{array}$ & $\begin{array}{l}\text { Post test mean } \\
\text { rank }\end{array}$ & $\mathbf{n}$ & $\%$ & $\begin{array}{l}\text { Pre test mean } \\
\text { rank }\end{array}$ & $\begin{array}{l}\text { Post test mean } \\
\text { rank }\end{array}$ \\
\hline \multicolumn{9}{|l|}{ Age } \\
\hline - 35 years and under & 31 & 62.0 & 23.95 & 26.32 & 36 & 72.0 & 22.31 & 24.97 \\
\hline \multirow[t]{3}{*}{ - 35 years and over } & 19 & 38.0 & 28.03 & 24.16 & 14 & 28.0 & 33.71 & 26.86 \\
\hline & & & $\mathrm{MWU}=246.500$ & $\mathrm{MWU}=269.000$ & & & $\mathrm{MWU}=137.000$ & $\mathrm{MWU}=233.000$ \\
\hline & & & $p=.33$ & $p=.60$ & & & $p=.01$ & $p=.68$ \\
\hline \multicolumn{9}{|l|}{ Educational status } \\
\hline - Primary school & 5 & 10.0 & 15.00 & 31.10 & 8 & 16.0 & 26.50 & 27.06 \\
\hline - Secondary school & 9 & 18.0 & 19.06 & 22.33 & 9 & 18.0 & 20.50 & 19.67 \\
\hline - High school & 20 & 40.0 & 26.15 & 23.73 & 20 & 40.0 & 20.30 & 22.53 \\
\hline \multirow[t]{3}{*}{ - University } & 16 & 32.0 & 31.59 & 27.75 & 13 & 26.0 & 36.35 & 33.15 \\
\hline & & & $\mathrm{KW}=7.226$ & $\mathrm{KW}=1.910$ & & & $\mathrm{KW}=10.865$ & $\mathrm{KW}=5.986$ \\
\hline & & & $p=.06$ & $p=.59$ & & & $p=.01$ & $p=.11$ \\
\hline \multicolumn{9}{|l|}{ Employment status } \\
\hline - Employed & 48 & 96.0 & 26.11 & 25.71 & 46 & 92.0 & 26.80 & 26.63 \\
\hline \multirow[t]{3}{*}{ - Unemployed } & 2 & 4.0 & 10.75 & 20.50 & 4 & 8.0 & 10.50 & 12.50 \\
\hline & & & $\mathrm{MWU}=225.500$ & $\mathrm{MWU}=281.000$ & & & $\mathrm{MWU}=220.500$ & $\mathrm{MWU}=178.500$ \\
\hline & & & $p=.16$ & $p=.65$ & & & $p=.02$ & $p=.06$ \\
\hline \multicolumn{9}{|l|}{ Place of residence } \\
\hline - City & 32 & 64.0 & 25.77 & 25.97 & 24 & 48.0 & 26.00 & 24.96 \\
\hline - District & 13 & 26.0 & 27.08 & 27.31 & 16 & 32.0 & 29.16 & 31.00 \\
\hline \multirow[t]{3}{*}{ - Village } & 5 & 10.0 & 19.70 & 17.80 & 10 & 20.0 & 18.45 & 18.00 \\
\hline & & & $\mathrm{KW}=0.959$ & $\mathrm{KW}=1.689$ & & & $\mathrm{KW}=3.382$ & $\mathrm{KW}=4.988$ \\
\hline & & & $p=.61$ & $p=.43$ & & & $p=.18$ & $p=.08$ \\
\hline \multicolumn{9}{|l|}{ Family type } \\
\hline - Nuclear family & 34 & 68.0 & 27.97 & 26.00 & 38 & 76.0 & 27.57 & 27.53 \\
\hline \multirow[t]{3}{*}{ - Extended family } & 16 & 32.0 & 20.25 & 24.44 & 12 & 24.0 & 18.96 & 19.08 \\
\hline & & & $\mathrm{MWU}=188.000$ & $\mathrm{MWU}=255.000$ & & & $\mathrm{MWU}=149.500$ & $\mathrm{MWU}=151.000$ \\
\hline & & & $p=.08$ & $p=.71$ & & & $p=.07$ & $p=.07$ \\
\hline \multicolumn{9}{|l|}{ Income level } \\
\hline - Sufficient & 23 & 46.0 & 31.11 & 22.54 & 16 & 32.0 & 34.38 & 32.00 \\
\hline $\begin{array}{l}\text { - Equal income and } \\
\text { expenses }\end{array}$ & 12 & 24.0 & 27.54 & 29.04 & 18 & 36.0 & 22.08 & 20.33 \\
\hline \multirow[t]{3}{*}{ - Insufficient } & 15 & 30.0 & 15.27 & 27.20 & 16 & 32.0 & 20.47 & 24.81 \\
\hline & & & $\mathrm{KW}=11.089$ & $\mathrm{KW}=1.929$ & & & $\mathrm{KW}=8.847$ & $\mathrm{KW}=5.511$ \\
\hline & & & $p=.00$ & $p=.38$ & & & $p=.01$ & $p=.06$ \\
\hline \multicolumn{9}{|l|}{ The number of children } \\
\hline - 1 child & 18 & 36.0 & 25.5 & 19.6 & 14 & 28.0 & 27.54 & 24.57 \\
\hline \multirow[t]{3}{*}{ - 2 and more } & 32 & 64.0 & 25.5 & 28.8 & 36 & 72.0 & 24.71 & 25.86 \\
\hline & & & $\mathrm{MWU}=288.000$ & $\mathrm{MWU}=182.500$ & & & $\mathrm{MWU}=223.500$ & $M W U=230.000$ \\
\hline & & & $p=1.000$ & $p=.03$ & & & $p=.538$ & $p=.778$ \\
\hline
\end{tabular}

\section{Discussion}

The participation of a new member to the family in the postpartum period requires the preparation and adjustment of the parents to the new roles and responsibilities. Like mothers, it is also necessary for fathers to acquire the necessary and Published by Sciedu Press sufficient knowledge and skills in order to adapt to the physiological and psychological changes they will experience in order to gain the role of fatherhood, to accept the baby and to participate in baby care. It is important that parents have adequate knowledge of baby care to be able to participate in it. ${ }^{[12]}$ The aim of this study was to evaluate the effectiveness 
of the training on "Basic Newborn Care" given to the fathers whose babies were in the neonatal intensive care unit.

It was determined that the scores of the fathers in younger age group were higher than those in the age group above 35 years in the experimental group after the theoretical and brochure training and the knowledge scores of the fathers in the age group over 35 years old in the control group were higher than those in the younger age group after the brochure education. However, there was no significant difference between the age group and the knowledge scores of the groups $(p>.05)$ (see Table 1). This result may be due to the fact that the younger fathers were mostly less experienced as it was their first fatherhood experience so they paid more attention to the training. Bal stated that as their knowledge level improved young fathers felt that they were adequately qualified for baby care and felt better at participating in neonatal care. ${ }^{[12]}$ Castillo et al. found that as the fathers' age increased, they were more willing to participate in baby care. ${ }^{[13]}$ In a study by Seçer et al., the fathers under 35 years of age were found to have higher levels of participation in baby care than the fathers over 36 years. ${ }^{[14]}$ Yeung et al. also reported that as the age of fathers increased, their participation in care decreased. ${ }^{[15]}$ The fact that the young fathers were more enthusiastic about participating in care of their babies compared with those over 35 may be due to having their first fatherhood excitement. In our study, it was also found that the fathers in the experimental group were more willing to participate in their baby care than those in the control group after discharge (see Table 2).

Table 2. Findings regarding baby care

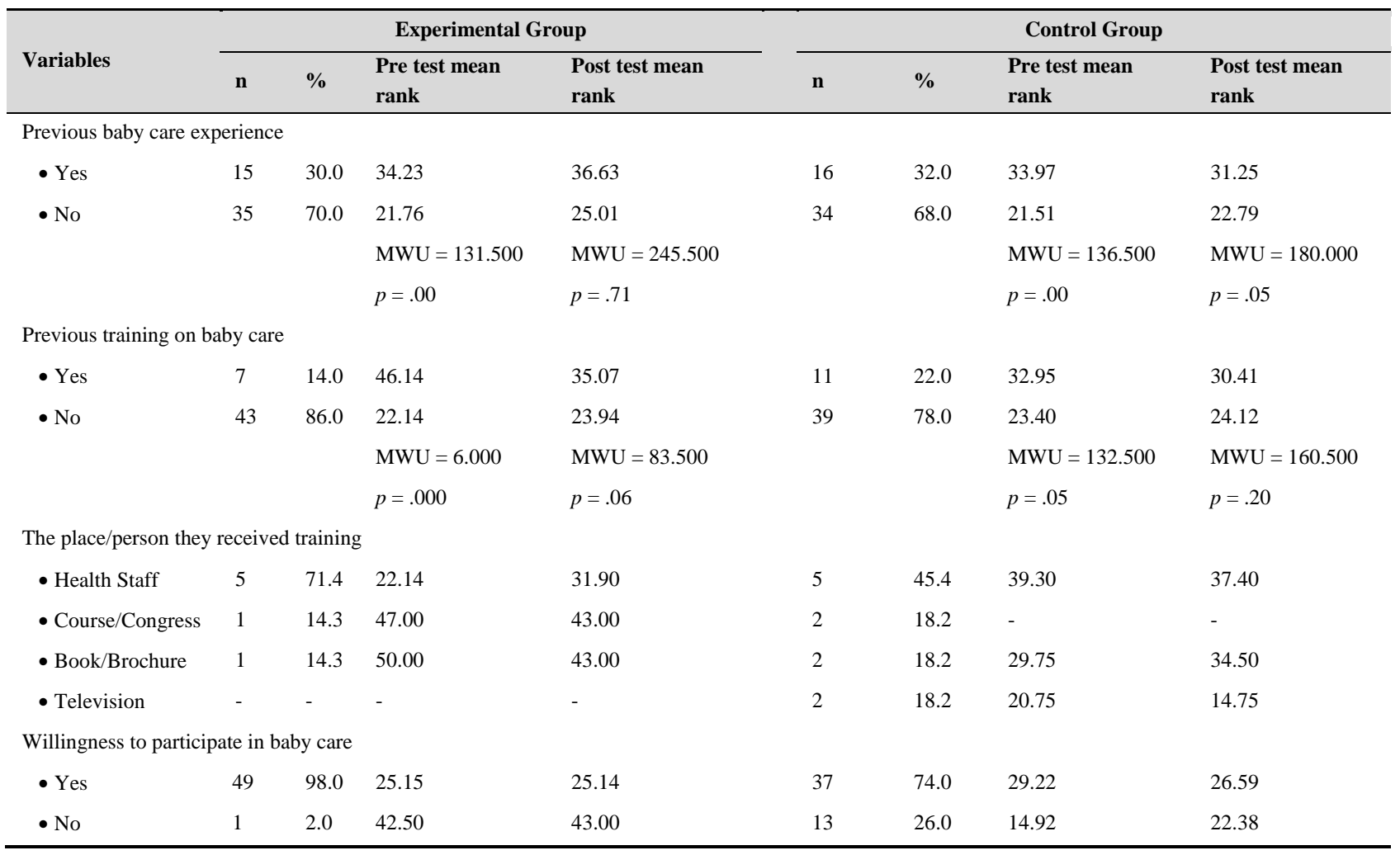

Table 3. The distributions of the pre/post training mean scores of the fathers in the experimental and control

\begin{tabular}{lllll}
\hline Knowledge scores & Pre training & Post training & $\mathbf{Z}$ & $p$ \\
\hline Experimental & $12.24 \pm 12.24$ & $42.98 \pm 3.70$ & $\mathrm{Z}=-6.157$ & .00 \\
Control & $12.48 \pm 8.46$ & $18.60 \pm 6.05$ & $\mathrm{Z}=-5.297$ & .00 \\
*MWU & $1,078.000$ & 5.000 & & \\
$p$ & .23 & .00 & & \\
\hline
\end{tabular}

Note. ${ }^{*} \mathrm{MWU}=$ Mann Whitney $\mathrm{U}$ 
The study revealed that the higher the education level the fathers had before training in the experimental group, the higher knowledge scores they had after the training and it was seen that the theoretical and brochure training were more effective in the primary school graduates in the experimental group. In the control group, the knowledge scores of the university graduates were found to be higher than those of the other groups before and after the training, and again the knowledge scores increased more in these fathers after the brochure training in this group (see Table 1). Contrary to our study, in a study by Seçer et al. it was stated that as the education level of the fathers increased, they regarded themselves as more adequate about fatherhood and their interest in it was more positive. ${ }^{[14]}$

The study also demonstrated that the post training scores of the fathers with nuclear family type in both groups increased. However, there was no statistically significant difference between the family type and the knowledge scores of the groups $(p>.05)$. Consistent with this result, in nuclear families, the father helps his wife in household affairs, takes care of his children and spends more time with his wife and children than the traditional father role (see Table 1).

Family income is among the causes for difficulty in parenting. ${ }^{[16]}$ In this study, it was seen that in terms of income status, the knowledge scores of the fathers whose income and expenses were equal in the experimental group increased more and in the control group those with insufficient in come level increased their knowledge scores thanks to the brochure training. Sevil and Özkan found that fathers with middle income levels felt more competent about childcare and participated more than those with high-income. ${ }^{[17]}$

The study demonstrated that the mean knowledge scores of the fathers with 2 children or more were found to be higher in both groups. There was a significant difference between the mean scores and the number of children in the experimental group $(p<.05)$. O'Connell's survey showed that as the number of children increased, the knowledge scores of the fathers increased and as a result, the fathers felt more competent in baby care and were more likely to participate in it. ${ }^{[18]}$ This result was thought to be due to the fact that fathers with more children were more experienced in child care (see Table 1).

The literature emphasizes the necessity of informing parents about baby care in prenatal and postnatal period. ${ }^{[19-21]}$ The knowledge of the father in the baby care can make him feel more comfortable about it and allow him to participate more in baby care. ${ }^{[12]}$ Our study indicated that the majority of the fathers in experimental and control groups did not receive baby care training before. The experienced fathers about

Published by Sciedu Press baby care had higher knowledge scores than the inexperienced ones (see Table 2). Similarly, Bal found that about half of the fathers participating in the survey did not receive any training on baby care. ${ }^{[12]}$

In our study, the majority of the fathers in both groups were reported to have received training from health care staff. In a study carried out by Premberg, ${ }^{[22]}$ it was found that the same way that it received from health personnel. In a study carried out by Bilgili, it was found that the rate of education received by the father from health personnel regarding baby care was higher than that of the mothers who received information mostly from books/brochures and television. ${ }^{[3]}$ In de Montigny's study, it was found that in the prenatal and postnatal period, fathers preferred to receive information about baby care from nurses. ${ }^{[23]}$ This situation shows that fathers do not have enough knowledge, and nurses and professional health care profession should take more responsibility in providing this information (see Table 2).

The knowledge level of the fathers included in the study on neonatal care was examined and their pre and post training scores obtained from the evaluation form were compared according to the experimental and control groups (see Table 3). In the experimental group, the pre-training knowledge scores which were $12.24 \pm 12.24$ increased up to $42.98 \pm 3.70$ after the training and it was found to be statistically significant $(\mathrm{Z}=-6.157, p=.00)$. In the control group, the knowledge scores of the fathers was $12.48 \pm 8.46$ after the brochure training during their babies' stay in neonatal intensive care unit and it increased to $18.60 \pm 6.05$ at the time of discharge and the difference was statistically significant $(Z=-5.297$, $p=.00$ ) (see Table 3). The increase in the knowledge scores of the fathers in the control group can be thought to be due to their increased awareness of baby care through the brochures they received. When the experimental and control groups were compared in terms of the knowledge scores, the pretraining scores were similar, whereas the post training scores in the experimental group were found to be significantly higher in the control group ( $p=.23, p=.00$ respectively) (see Table 3). It can be suggested that the theoretical and visually enriched brochure education given to the experimental group made the difference compared to control group (see Table 3).

\section{Conclusions}

The baby care knowledge levels of the fathers both in the experimental and control groups were low $(12.24 \pm 12.24$; $12.48 \pm 8.46$ respectively) prior to the training. At the end of the training, while the knowledge levels of the fathers in the experimental group increased at a high level (42.98 \pm 3.70$)$, the knowledge scores of the fathers in the control group in- 
creased but still remained under the middle level (18.60 \pm $6.05)$. It was determined that both the theoretical and visually enriched brochure training in the experimental group was more effective than only the brochure training. The factors such as being in a young age group, low education level, being unemployed, living in a village, having a low income, having a single child, not having baby care experience before can be considered as risk factors. It is necessary to provide the appropriate physical environment for prenatal and postnatal training for fathers and to encourage them to support their wives during pregnancy. Additionally, nurses should focus on the training regarding the common problems encountered in the neonatal period, the fathers' first physical contact with their babies should be assisted by nurses to strengthen the bonding between them and the baby after birth and both the theoretical and practical training for the fathers on neonatal care should be increased.

\section{Conflicts of Interest Disclosure}

The authors declare they have no conflicts of interest.

\section{REFERENCES}

[1] Rutter M, Caspi A, Fergusson D. Sex Differences in Developmental Reading Disability: New Findings From 4 Epidemiological Studies. JAMA. 2004; 291(16): 2007-12. PMid: 15113820 https://doi.org/10.1001/jama.291.16.2007

[2] Taşkın L. Doğum ve Kadın Sağlığı Hemşireliği Ankara [Maternity and Women Health Nursing]. Sistem Ofset Matbaacilık. 2009.

[3] Bilgili N. Yenidoğan Yoğun bakım Ünitesinde Bebeği Yatan Ebeveynlerin Yenidoğan Bakımına Yönelik Bilgi Düzeyleri [Information Levels About Newborn Care of the Parents of The Babies Lining at the Newborn Intensive Care]. Yüksek Lisans Tezi, On dokuz Mayıs Üniversitesi Sağlık Bilimleri Enstitüsü. Samsun. 2009.

[4] David M. Ethnic Turkish Fathers in Birth Support Roles in A Berlin Labour and Delivery Room-Motives, Preparation and Incidence in A 10-Year Comparison. Journal of Psychosomatic Obstetrics and Gynecology. 2009; 5-10.

[5] Beydağ K. Doğum sonu dönemde anneliğe uyum ve hemşirenin rolü, Kor Hek [Adaptation to Motherhood in the Postpartum Period and the Nurse's Role, Kor Hek]. 2007; 6(6): 479-484.

[6] Sarkadi A, Widarsson M, Kerstis B, et al. Support Needs of Expectant Mothers and Fathers: A Qualitative Study. J Perinat Educ. 2012; 21(1): 36-44. PMid: 23277729. https://doi .org/10.1891/10 58-1243.21.1.36

[7] World Health Organisation. Fatherhood and Health Outcomes in Europe. Copenhagen; 2005.

[8] Alvergne A, Faurie C, Raymond M. Variation in Testosterone Levels and Male Reproductive Effort: Insight from A Polygynous Human Population. Horm Behav. 2009; 56(5): 491-7. PMid: 19664637. https://doi.org/10.1016/j.yhbeh.2009.07.013

[9] Gettler LT, McDade TW, Feranil AB, et al. Prolactin, Fatherhood, And Reproductive Behavior in Human Males. J Phys Anthropol 2012b; 148: 362-370. PMid: 22576125. https ://doi .org/10.1 002/ajpa. 22058

[10] Muller MN, Marlowe FW, Bugumba R, et al. Testosterone and Paternal Care in East African Foragers and Pastoralists. Proc R Soc B 2009; 276: 347-354. PMid: 18826936. https ://doi.org/10.109 $8 / \mathrm{rspb} .2008 .1028$

[11] Gordon I, Zagoory-Sharon O, Leckman J, et al. Oxytocin and The Development of Parenting in Humans. Biological Psychiatry. 2010; 10: 1016. https://doi.org/10.1016/j. biopsych. 2010.02.005

[12] Bal S. İlk Kez Babalık Deneyimi Yaşayan Erkeklerin Bebek Bakımına Katılmaya İlişkin Görüşleri Ve Bakıma Katılma Durumları [The Opinions and Involvement Status of the Men Experiencing
Parenting for the First Time on Babysitting]. Yüksek Lisans Tezi Hacettepe Üniversitesi Sağlık Bilimleri Enstitüsü, Ankara. 2014.

[13] Castillo JW. Fathering: The Relationship Between Fathers' Residence, Fathers' Socio-Demographic Characteristics, And Father Involvement. Maternal Child Health Journal. 2011; 15: 1342-1349. PMid: 20848169. https://doi.org/10.1007/s10995-010-0 684-6

[14] Seçer Z, Çeliköz N, Yaşa S. Bazı Kişisel Özelliklerine Göre Okul öncesi Eğitim Kurumlarına Devam Eden Çocukların Babalarının Babalığa Yönelik Tutumları [According to some personal characteristics, the attitudes of the fathers of the pre-school children towards the fatherhood]. Sosyal Bilimler Enstitüsü Dergisi Selçuk Üniversitesi. 2007; 18: 425-438.

[15] Yeung WJ, Sandberg JF, Davis-Kean PE, et al. Children's Time With Fathers in Intact Families. Journal of Marriage \& Family. 2001; 63(1): 136-154. https://doi.org/10.1111/j.1741-3737.2001.001 $36 . x$

[16] T.C. Sağlık Bakanlığı Temel Sağlık Hizmetleri Genel Müdürlüğü [Ministry of Health General Directorate of Primary Health Care Services]. Çocuğun Psikososyal Gelişimini Destekleme Programı Görüşme Rehberi. 2008.

[17] Sevil ÜÖ. Fathers' Functional Status During Pregnancy and The Early Postnatal Period. Midwifery. 2009; 25: 665-672. PMid: 18321620. https://doi.org/10.1016/j.midw . 2007.12.001

[18] O'Connell M. Where's Papa? Father's role in child care. Washington, DC: Population Reference Bureau, Inc.; 1993.

[19] Carter MW, Speizer I. Salvadoran Fathers' Attendance at Prenatal Care, Delivery, And Postpartum Care. Rev Panam Salud Publica. 2005; 18(3): 149-56. PMid: 16269116. https://doi.org/10.1 590/S1020-49892005000800001

[20] Draper H. Paternity Fraud and Compensation for Misattributed Paternity. Journal of Medical Ethics. 2007; 33: 475-480. PMid: 17664309. https://doi.org/10.1136/jme.2005.013268

[21] Mcveigh CJ. Fathers' Functional Status Six Weeks Following the Birth of a Baby: A Queensland Study. Journal of Australion Midwifery. 2005; 18(1): 22-25. https://doi.org/10.1016/S144 8-8272(05) 80016-1

[22] Premberg A. Experiences of The First Year as Father. Scand J Caring Sci. 2008; 22: 56-63. PMid: 18269423. https://doi.org/10.1 $111 / j \cdot 1471-6712.2007 .00584 . x$

[23] de Montigny FLC. Fathers' Perceptions of The Immediate Postpartal Period. J Obstet Gynecol Neonatal Nurs. 2004; 33(3): 328-339. PMid: 15180196. https://doi.org/10.1177/0884217504266012 